\title{
Effects of dietary fish oil supplementation on performance, meat quality, and cecal fermentation of growing rabbits
}

\author{
M. Rodriguez, ${ }^{*}$ M. D. Carro, V. Valiente, N. Formoso-Rafferty, and P. G. Rebollar
}

\begin{abstract}
The objective of this study was to investigate the effect of dietary supplementation with fish oil on growth performance (during all fatening period), carcass characteristics and fatty acid (FA) profile of muscle and fat tissues (at slaughter), as well as cecal fermentation and ileal mucosa morphology of growing rabbits (at 30,45 , and $60 \mathrm{~d}$ of age). Two isonitrogenous and isoenergetic diets, only differing in their fat source, were formulated and provided each to 24 does (12 per diet) and their offspring during pregnancy and lactation. The control diet contained 4.59 $\mathrm{g}$ of $\mathrm{n}-3$ per $100 \mathrm{~g}$ of total $\mathrm{FA}$, and the enriched diet contained $14.9 \mathrm{~g}$ of $\mathrm{n}-3$ per $100 \mathrm{~g}$ of total FA. From weaning ( $30 \mathrm{~d}$ of age) to slaughter $(60 \mathrm{~d})$, the litters ( 12 per diet; 8 kits each) continued fed the corresponding experimental diet. There were no differences $(P>$ 0.05 ) between groups in ADFI, ADG and G:F ratio during the growing period. At slaughter, BW, full gastrointestinal tract weight, carcass yield, meat color and $\mathrm{pH}$, drip loss percentage, content of scapular fat and tissue composition of the left hind leg were similar between groups $(P>0.05)$, but perirenal fat was lower
\end{abstract}

\section{INTRODUCTION}

Increasing the quality of animal products in production systems that also enhance animal welfare is an
$(P=0.020)$ and skin weight and abdominal fat tended to be lower ( $P=0.055$ and $P=0.063$, respectively) in enriched rabbits than in control ones. Total PUFA content in both LM and perirenal fat was greater ( $P=$ 0.021 and $<0.001$, respectively) in enriched rabbits, that also showed lower $n-6 / 11-3$ ratios in LM ( 1.61 vs. $5.80 ; P<0.00 \mathrm{I})$ and perirenal fat $(4.7 \mathrm{I}$ vs. $12.0 ; P$ $<0.001)$ than those fed the control diet. Cecal concentrations of total VFA were greater $(P<0.001)$ in enriched than in control group at 30,45 and $60 \mathrm{~d}$ of age, but diet did not affect $(P \geq 0.332)$ VFA profile, with the exception of a lower $(P=0.013)$ proportion of minor VFA (sum of isobutyrate, isovalerate, and valerate) in control group. Diet did not affect $(P>0.255)$ either $\mathrm{pH}$ and $\mathrm{NH}_{3}-\mathrm{N}$ concentrations in the cecum or ileal morphology (crypt depth and villi length). The results showed that dietary fish oil supplementation enhanced beneficial long-chain n-3 FA and decreased $n-6 / n-3$ ratio in rabbit meat and fat, being healthier for human consumption, without having negative effects on growth performance, cecal fermentation, and ileal morphology or carcass characteristics. important goal of animal nutritionists. Human dietary recommendations often focus on the need of increasing the intake of long chain n-3 PUFA (18, 20, and 22 carbon atoms) due to their beneficial effects on health (Gil and Gil, 2015). Dietary supplementation of long chain n-3 PUFA has been shown to increase their content in rabbits' meat (Xiccato, 1999; Peiretti, 2012; Bianchi et al., 2009), and meat content in eicosapentaenoic (C20:5n-3), docosapentaenoic (C22:5n-3), and docosahexaenoic (C22:6n-3) acids was reported to be higher by enriching with fish than with vegetable 
oils (Benatmane et al., 2011; Tres et al., 2014). These long chain n-3 fatty acids (FA) are implicated in the development of the immune response (Fortun-Lamothe and Boullier, 2007), and their dietary supplementation can increase both kits BW at birth (Rebollar et al., 2014) and postweaning viability (Maertens et al., 2005) Moreover, dietary supplementation with vegetable fats can modify feed efficiency and productive performance in rabbits (Peiretti et al., 2007; Casado et al., 2013), and it has been reported that medium-chain FA (caprilyc and capric) acids can alter the intestinal microbiota, thus affecting cecal fermentation (Marounek et al., 2002) and the development of pathogenic strains (Skrivanová et al., 2009). Nonetheless, studies with PUFA of marine origin are scarce (Castellini et al., 2004; Kowalska and Bielanski, 2009) and have focused on meat characteristics. Our hypothesis was that fish oil (rich in C20:5n-3 and $\mathrm{C} 22: 6 \mathrm{n}-3$ ) supplementation to rabbits would influence meat FA profile, but might also modify cecal fermentation and affect positively animal performance by reducing morbidity and/or mortality. The aim of this study was to evaluate the influence of a supplement derived from fish oil on performance, meat quality, ileal morphology, and cecal fermentation of growing rabbits.

\section{MATERIALS AND METHODS}

All experimental procedures used were approved by the Animal Ethics Committee of the Community of Madrid (Reference Procedimiento experimental 302/15), and were in compliance with the Spanish Guidelines for Care and Use of Animals in Research (Boletín Oficial del Estado, 2013). Temperature $\left(19-22^{\circ} \mathrm{C}\right)$, air circulation ( 15 renovations per $h$ ), humidity $(50 \pm 5 \%$ ), and light program ( $16 \mathrm{~h}$ of light and $8 \mathrm{~h}$ of darkness) of the building were maintained through the trial.

\section{Experimental Diets}

Two isoenergetic, isoproteic, and isofibrous diets were formulated following the nutritional recommendations of De Blas and Mateos (2010). Both diets had the same basal mixture of ingredients and only varied in the type of fat added: either $7.5 \mathrm{~g} / \mathrm{kg}$ of lard (control group) or $15 \mathrm{~g} / \mathrm{kg}$ of a commercial supplement (Optomega- 50 ; Optivite International Ltd., Barcelona, Spain) consisting in a concentrated mixture of n-3 PUFA derived from salmon oil (enriched group). According to the manufacturer, Optomega- 50 contained $50 \%$ of ether extract $(35 \%$ of $\mathrm{n}-3$ and $8 \%$ of $\mathrm{n}-6)$ and vitamin $E(2,500 \mathrm{mg} / \mathrm{kg})$ on a mineral based carrier. In order to equal the carrier of Optomega-50,7.5 g/kg of sepiolite were included in the control diet. The ingredient and chemical composition of diets is given in Table 1, and FA profiles are shown in
Table 2. Only one batch of each diet was used during the study. Diets were prepared at the beginning of the trial, vacuum-packed and stored at $5^{\circ} \mathrm{C}$ to protect against lipid oxidation and other degradative processes. Samples of each diet were collected weekly, maintained at $5^{\circ} \mathrm{C}$ and composited at the end of the trial for chemical analysis.

Table 1. Ingredients and chemical composition of control diet and an enriched diet with a supplement based on n-3 PUFA (Enriched)

\begin{tabular}{|c|c|c|}
\hline \multirow[b]{2}{*}{ Item } & \multicolumn{2}{|c|}{ Diet } \\
\hline & Control & Enriched \\
\hline \multirow{2}{*}{\multicolumn{3}{|c|}{$\begin{array}{l}\text { Ingredient composition, g per } 100 \mathrm{~g} \\
\mathrm{l} 00 \mathrm{~g} \text { diet (as-fed basis) }\end{array}$}} \\
\hline & & \\
\hline Wheat bran & 30.0 & 30.0 \\
\hline Barley grain & 11.1 & 11.1 \\
\hline Sunflower meal & 19.9 & 19.9 \\
\hline Palm kernel & 6.00 & 6.00 \\
\hline Lucerne meal & 10.0 & 10.0 \\
\hline Barley sprouts & 5.00 & 5.00 \\
\hline Sugarbeet pulp & 5.70 & 5.70 \\
\hline Sugarcane molasses & 3.00 & 3.00 \\
\hline Wheat straw & 4.20 & 4.20 \\
\hline Lard & 0.75 & - \\
\hline Sepiolite & 0.75 & - \\
\hline Optomega $50^{1}$ & - & 1.50 \\
\hline Calcium carbonate & 1.90 & 1.90 \\
\hline Sodiun chloride & 0.60 & 0.60 \\
\hline Lysine & 0.17 & 0.17 \\
\hline Choline chloride & 0.03 & 0.03 \\
\hline Organic acids & 0.07 & 0.07 \\
\hline Min-vitpremix ${ }^{2}$ & 0.30 & 0.30 \\
\hline Antioxidants $^{3}$ & 0.33 & 0.33 \\
\hline Zinc bacitracin premix ${ }^{4}$ & 0.20 & 0.20 \\
\hline \multicolumn{3}{|l|}{$\begin{array}{l}\text { Chemical composition, g per } 100 \mathrm{~g} \\
\text { DM unless otherwise stated }\end{array}$} \\
\hline Gross energy, $\mathrm{MJ} / \mathrm{kg}$ & 16.4 & 16.5 \\
\hline DM, g per $100 \mathrm{~g}$ (as-fed basis) & 90.6 & 90.4 \\
\hline Ash & 8.11 & 7.88 \\
\hline $\mathrm{CP}$ & 16.0 & 16.0 \\
\hline Ether extract & 31.6 & 31.4 \\
\hline NDF & 33.2 & 33.5 \\
\hline $\mathrm{ADF}$ & 16.1 & 16.3 \\
\hline $\mathrm{ADL}$ & 3.98 & 4.00 \\
\hline
\end{tabular}

${ }^{1}$ A commercial product containing salmon fish oil. According to the manufacturer it contains $50 \%$ of ether extract ( $35 \%$ of $n-3$ and $8 \%$ of $n-6)$ and vitamin $E(2.500 \mathrm{mg} / \mathrm{kg})$ on a mineral based carrier.

-Mineral and vitamio prenix supplied per $\mathrm{kg}$ of complete diet: vitamin A 9,999.9 IU; vitamin D 1,080 IU; vitamin E, $200 \mathrm{mg} / \mathrm{kg}$; vitamin K3: $1.7 \mathrm{mg}$ : Thiamine: $1.7 \mathrm{mg}$ : Riboflavin: $4.3 \mathrm{mg}$; Pantotheic acid: 13.6 mg; Pyridoxine: $1.7 \mathrm{mg}$; Mn:22.7 mg; Co:595 $\mu \mathrm{g}$; Se: $140 \mu \mathrm{g}$; I:1.2 mg.

${ }^{3}$ Supplied per $\mathrm{kg}$ of diet: [E320 Butilhidroxianisol (BHA) + E324 Etoxicjuina+E321 Butilhidroxitolueno (BHT) $30.000 \mathrm{mg}$; E562 sepiolita $910,000 \mathrm{mg}$ ( Trow Nutrition Spain, SA, Madrid. Spain); 3,000 mg Luctanox (Lucta. Barcelona, Spain; Luctanox was composed of ethoxyquin (E324), propylgalate (E310), citric acid (E330), sodium phosphate (E339), and colloidal silicic acid (E551a).

${ }^{4}$ Contained $100 \mathrm{mg}$ of zinc-bacitracin/kg (Andrés Pintaluba S.A., Reus, Spain). 
Table 2. Fatty acid composition (g per $100 \mathrm{~g}$ of total fatty acid methyl esters) of control diet and an enriched diet with a supplement based on n-3 PUFA (Enriched)

\begin{tabular}{lcc}
\hline \hline & \multicolumn{2}{c}{ Diet } \\
\cline { 2 - 3 } Fatty acid & Control & Enriched \\
\hline C12:0 & 6.33 & 6.36 \\
C14:0 & 5.32 & 6.10 \\
C16:0 & 18.3 & 16.62 \\
C18:0 & 5.42 & 2.76 \\
Total SFA & 35.4 & 31.8 \\
C16:1n-7 & 1.34 & 1.68 \\
C18:1n-9 & 24.1 & 17.7 \\
C18:1n-7 & 1.59 & 1.23 \\
C20:1n-9 & 1.31 & 1.21 \\
Total MUFA & 28.3 & 21.8 \\
C18:2n-6 & 32.7 & 31.5 \\
C18:3n-3 & 4.08 & 4.45 \\
C18:4 n-3 & 0.51 & 2.16 \\
C20:5n-3 & nd ${ }^{1}$ & 3.39 \\
C22:5n-3 & nd & \\
C22:6n-3 & $n d^{1}$ & 0.92 \\
Total PUFA & 36.6 & 4.00 \\
n-9 & 25.4 & 46.4 \\
n-6 & 33.5 & 18.9 \\
n-3 & 4.59 & 32.8 \\
n-6/n-3 ratio & 7.29 & 14.9 \\
Unsaturation index ${ }^{2}$ & 1.15 & 2.20 \\
\hline & & 1.27 \\
\hline & &
\end{tabular}

${ }^{1}$ nd $=$ not detected.

${ }^{2}$ Calculated as the sum of the unsaturated fatty acids, each multiplied by the number of double bonds in their chain, and divided by 100 .

\section{Animals and Experimental Design}

The litters from 24 primiparous rabbit does that had been fed the experimental diets ( 12 control and 12 enriched does) during pregnancy and lactation were used in the study. Results on the effects of diet supplementation with n-3 PUFA on endocrine, reproductive and productive responses of rabbit does have been reported by Rebollar et al. (2014), and those on plasma metabolites in their offspring by Rodríguez et al. (2017). All kits were weaned after $30 \mathrm{~d}$ of lactation. They were weighed and subsequently standardized to 8 kits per litter (kits with a BW similar to the average litter BW removing the outliers). Each litter was housed in a flat-deck cage (60 $\times 50 \times 33.5 \mathrm{~cm})$. The 24 litters (192 kits in total) were divided into 4 homogeneous groups (6 litters each; 2 groups/diet) according average BW. The initial average BW of kits was $711 \pm 25.9$ and $710 \pm 28.3 \mathrm{~g}$ for control and enriched group, respectively. Rabbits continued to be fed their ad libitum maternal diet through the growing period and viability of rabbits was monitored every day. The experimental design is shown in Fig. 1.

\section{Productive Performance and Carcass Characteristics}

Feed intake, productive performance and carcass quality were measured in 6 litters per diet ( 48 rabbits per diet). Live BW and feed consumption were determined weekly in each cage to calculate ADFI, ADG and G:F. At d 60, all rabbits (48 rabbits per diet) were

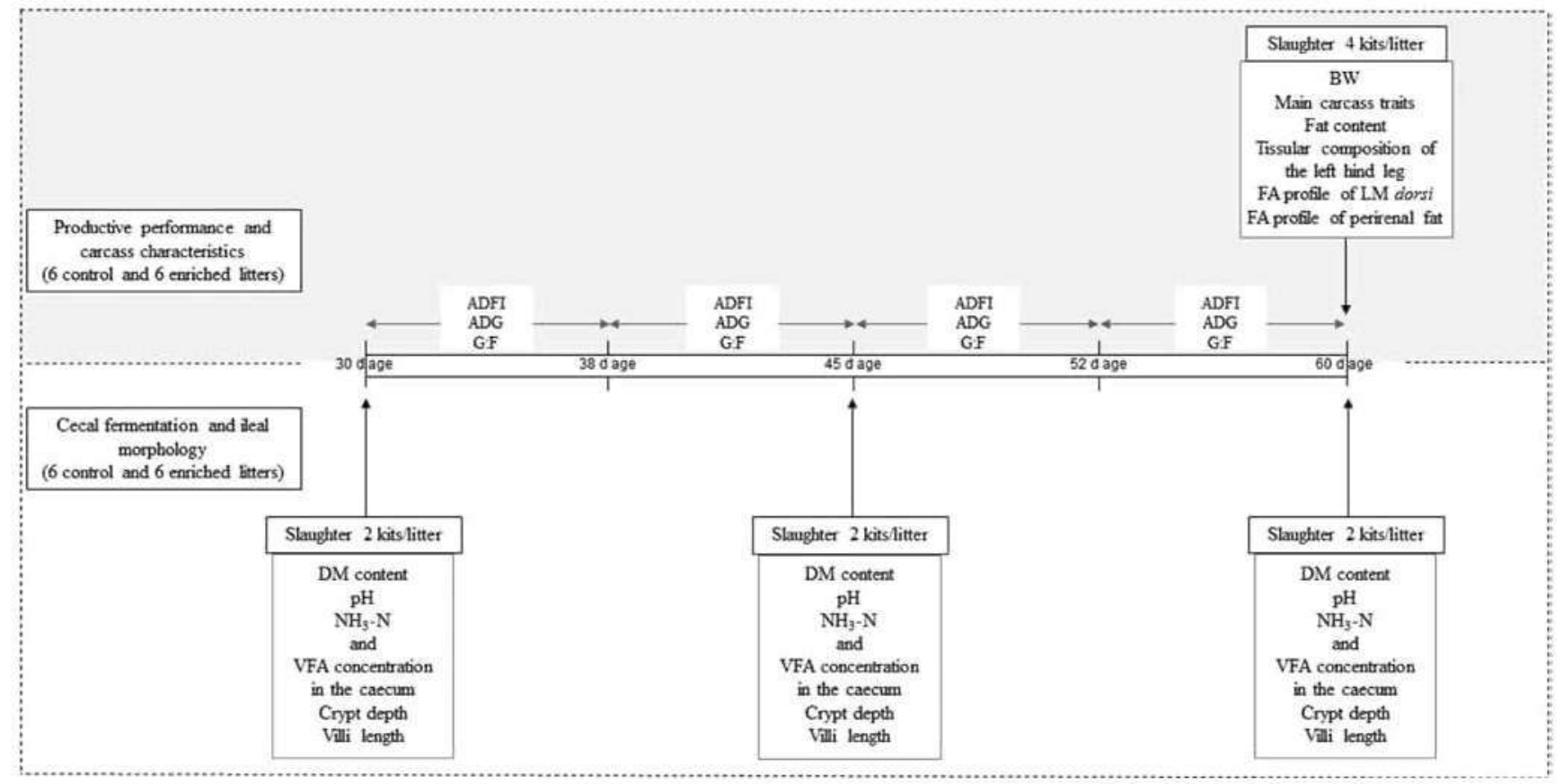

Figure 1. Sampling timeline of different variables related to productive performance and carcass characteristics, as well as cecal fermentation and ileal morphology of kits during their growing period. 
weighed and 4 animals from each litter, having a BW similar to the average litter BW, were stunned at low voltage $(90 \mathrm{~V} ; 5 \mathrm{~s})$. Animals were then bled by cutting the carotid arteries and jugular veins. All further procedures followed the recommendations of the World Rabbit Science Association described by Blasco et al (1993). The full gastrointestinal tract, skin, distal legs and tail, and urogenital tract were removed. Carcasses (with the head, heart, lungs, liver, kidneys, perirenal fat, and scapular fat) were weighed, and then the perirenal, suprascapular, and abdominal fat were removed and weighed individually. Samples ( 2 to $3 \mathrm{~g}$ ) of perirenal fat and LM (dorsal portion) were taken and immediately frozen $\left(-20^{\circ} \mathrm{C}\right)$ until lyophilization and analysis of FA profile. Muscle $\mathrm{pH}$ was measured on the 10th rib face of the LM using a portable Crisson $25 \mathrm{pHmeter}$ with a penetration electrode $5053 \mathrm{~T}$ (Crisson Instruments, Barcelona, Spain) at $0 \mathrm{~min}, 30 \mathrm{~min}$, and $24 \mathrm{~h}$ post mortem. Meat color was assessed $30 \mathrm{~min}$ after slaugther in the LM according to the Commission International de L'Eclairage (CIE; 2004) system, and was reported as $\mathrm{L}^{*}$ (lightness), $\mathrm{a}^{*}$ (redness), and $\mathrm{b}^{*}$ (yellowness) Color was determined using a Konica Minolta CM-700d colorimeter (Azuchi-Machi Higashi-Ku, Osaka 541, Japan) under daylight illumination and a $45 / 0$ viewing angle. The left hind leg was separated, weighed and vacuum packaged until dissection and determination of the amount of muscle, bone and fat by weight (Precisa 125A precision balance, Precisa Gravimetrics AG, Dietikon, Switzerland). Finally, carcasses were chilled to $5^{\circ} \mathrm{C}$ for $24 \mathrm{~h}$ in a ventilated room, and weighed to calculate drip loss percentage and carcass yield.

\section{Cecal Fermentation and Ileal Morphology}

The other 6 litters per diet ( 48 rabbits per diet) were used to assess the influence of the experimental diets on cecal fermentation and ileal morphology. Two rabbits per litter ( 12 kits per diet), with a BW similar to the average litter BW, were slaughtered by cervical dislocation at 30 (weaning), 45 , and $60 \mathrm{~d}$ of age. The cecum was removed and its full weight was recorded. The cecal content was then extracted, weighed, homogenized, and the $\mathrm{pH}$ immediately measured with a Crison Basic $20 \mathrm{pHmeter}$ (Crison Instruments, Barcelona, Spain). About $2 \mathrm{~g}$ of cecal content were weighed, mixed with $2 \mathrm{~mL}$ of $0.5 \mathrm{NHCl}$, and immediately frozen $\left(-20^{\circ} \mathrm{C}\right)$ until analysis of $\mathrm{NH}_{3}-\mathrm{N}$ and VFA concentrations. The remaining cecal content was used to detemine DM content.

In addition, a sample from the ileum $(4 \mathrm{~cm})$ was taken next to the last Peyer's patch from each animal to study mucosa morphology. Samples were preserved in a formaldehyde solution $(10 \% ; \mathrm{vol} / \mathrm{vol})$, and were later gradually dehydrated with increasing concentrations of ethyl alcohol ( 50 to $100 \%$ ). The dehydrated samples were embedded in paraffin and stained with hematoxylineosin before cutting histological sections of $5 \mu \mathrm{m}$. The sections were analyzed by light microscopy (Olympus BX40; Olympus Optical Co., Hamburg, Germany) using an image analyzer (Soft Imaging System, Olympus, $\mathrm{GmbH}$, Hamburg, Germany). Villi length (from the top of the villi to the villi crypt junction) and depth of corresponding crypts were measured according to Hampson (1986) in 4 cross sections from the mean value of 30 vertically-oriented villi per animal. Due to a problem during the storage of the samples taken at weaning ( $30 \mathrm{~d}$ of age), they could not be analyzed and ileal morphology values for this sampling are not reported.

\section{Chemical Analyses}

Chemical analysis of experimental diets followed the official methods of the AOAC (2000) for DM (oven drying method: 934.01), ash (muffle furnace incineration: 923.03), ether extract (solvent extraction: 920.39), and CP (Dumas method: 968.06; FP-528 LECO Corportation, St. Joseph, MI) determinations. Gross energy was determined by combustion in an adiabatic calorimetric pump (model 1356, Parr Instrument Company, Moline, IL). The NDF, ADF, and ADL content was determined according to the sequential method of Van Soest et al. (1991) using an ANKOM220 Fiber Analyzer unit (ANKOM Technology Corporation, Fairport, NY). Sodium sulphite and heat-stable amylase were used in the sequential analysis of NDF, ADF, and $\mathrm{ADL}$, and they were expressed exclusive of residual ash.

The extraction of lipids from dietary samples followed the procedure of Sukhija and Palmquist (1988) Briefly, ground samples (I mm screen; $200 \mathrm{mg}$ ) were mixed with $\mathrm{I} \mathrm{mL}$ of toluene containing $\mathrm{I} \mathrm{mL}$ of internal standard (pentadecanoic acid (C15:0), Sigma-Aldrich, Madrid, Spain) of $10 \mathrm{mg} / \mathrm{mL}$ concentration, $1 \mathrm{~mL}$ of toluene and $3 \mathrm{~mL}$ of freshly made $5 \%$ methanolic $\mathrm{HCl}$ in a culture tube. Tubes were capped, vortexed $(1 \mathrm{~min})$ and heated for $2 \mathrm{~h}$ in a shaking water-bath at $70^{\circ} \mathrm{C}$. After tempering, $5 \mathrm{~mL}$ of $5 \%$ potassium carbonate solution were slowly added and the mixture was vigorously vortexed and centrifuged ( $5 \mathrm{~min}, 3,000 \mathrm{mpm}$ ). The upper phase (3 phases are formed) was dried with anhydrous sodium sulphate and collected for FA analysis as described below. Lipids from muscle samples were extracted using the procedure described by Segura and López-Bote (2014). Briefly, lyophilized samples (200 mg; in triplicate) were homogenized in dichloromethane:methanol (8:2; vol/vol) using a mixer mill (MM400; Retsch Technology, Stuttgart, Germany). The final biphasic system was separated by centrifugation. Solvent was evaporated under nitrogen stream, lipids were dried 
by vacuum desiccation and total lipid content was determined gravimetrically. Fatty acid methyl esters were prepared from total lipids by transesterification using a mixture of sodium methylate-methanol and methylated in the presence of sulphuric acid as described by Segura and Lopez-Bote (2014). The fatty acid methyl esters were separated using a gas chromatograph (HP 6890 Series GC System; Hewlett Packard Co., Avondale, PA) equipped with a flame ionization detector and a HPInnowax polyethylene glycol column $(30 \mathrm{~m} \times 0.316 \mathrm{~mm}$ $\times 0.25 \mu \mathrm{m} ; \mathrm{J} \& W$ Scientific/Agilent Technologies, Santa Clara, CA). Nitrogen was used as a carrier gas.

Cecal samples were thawed at $4^{\circ} \mathrm{C}$, homogenized, centrifuged $\left(14,000 \mathrm{rpm}, 15 \mathrm{~min}, 4^{\circ} \mathrm{C}\right)$ and the supernatant was used for $\mathrm{NH}_{3}-\mathrm{N}$ and VFA analyses. The analysis of the ammonia concentration was performed by the colorimetric technique described by Weatherburn (1967). Preparation of samples and analysis of VFA concentration followed the procedures described by GarciaMartinez et al. (2005). Briefly, $1.0 \mathrm{~mL}$ of the supernatant was mixed with $0.5 \mathrm{~mL}$ of a deproteinizing solution ( $10 \%$ metaphosphoric acid and $0.06 \%$ crotonic acid) and the obtained mixture was allowed to stand for $24 \mathrm{~h}$ at $4^{\circ} \mathrm{C}$ Samples were centrifuged $\left(14,000 \mathrm{rmm}, 15 \mathrm{~min}, 4^{\circ} \mathrm{C}\right)$ and the supematant was transferred to chromatography vials The VFA concentration was determined by gas chromatography using a Pelkin Elmer Autosystem XL gas chromatograph (PerkinElmer Inc., Shelton, CT) equipped with an automatic injector, detector flame ionization and a semi-capillary column TR-FFAP $30 \mathrm{~m} \times 0.53 \mathrm{~mm} \times 1$ $\mu \mathrm{m}$ (Supelco, Barcelona, Spain).

\section{Calculations and Statistical Analyses}

Unsaturation index of diets, muscle and fat were calculated as the sum of the unsaturated FA, each multiplied by the number of double bonds in their chain, and divided by 100 . Atherogenic and thrombogenic index of muscle and fat were calculated according to the equations proposed by Ulbricht and Southgate (1991), where MUFA represent the content of monounsaturated fatty acids.

$$
\begin{aligned}
& \text { Atherogenic index }=(\mathrm{C} 12: 0+4 \times \mathrm{Cl} 4: 0+\mathrm{Cl} 6: 0) \\
& /(\Sigma \text { MUFA }+\Sigma \mathrm{n}-6+\Sigma \mathrm{n}-3)
\end{aligned}
$$

Thrombogenic index $=(\mathrm{Cl} 4: 0+\mathrm{Cl}$ 6:0 $0+\mathrm{Cl} 8: 0) /[0.5$

$\times \Sigma$ MUFA $+0.5 \times \Sigma \mathbf{n}-6+3 \times \Sigma \mathbf{n}-3+(\Sigma \mathbf{n}-6 / \Sigma \mathbf{n}-6)]$

The experimental unit for ADFI, ADG, G:F, cecal fermentation parameters, and ileal morphology values measurements was the cage, whereas the individual rabbit was the experimental unit for carcass and meat characteristics. Data on ADFI, ADG, G:F, cecal fermentation, and ileal morphology were analyzed as a re- peated measures ANOVA using the MIXED procedure of SAS (version 9.2; SAS Inst. Inc., Cary, NC). The statistical model included diet, time (sampling day), and the interaction between diet and time as fixed effects The rest of the data were analyzed by the same model excluding the effects of time. All means were compared using a protected $t$-test, and significance was declared at $P<0.05$, and $0.05<P<0.10$ values were considered to be a trend. Results are presented as least squares means.

\section{RESULTS AND DISCUSSION}

Experimental diets were formulated with the same ingredients, and were isoenergetic and isoproteic in order to avoid confounding effects of different ingredients and/or different energy levels due to fat supplementation. As shown in Table 2, total PUFA concentration and $n-6 / n-3$ ratio were 1.3 -fold higher and 3.3-fold lower, respectively, in the enriched diet compared with the control one. No $\mathrm{C} 20: 5 n-3, \mathrm{C} 22: 5 n-3$ or $\mathrm{C} 22: 6 \mathrm{n}-3$ were detected in the control diet but they were present in the enriched diet, with proportions ranging from 0.92 to $4.00 \mathrm{~g} / 100 \mathrm{~g}$ of total fatty acids methyl esters.

\section{Productive Performance and Carcass Characteristics}

No mortality or morbidity was registered through the trial. As shown in Table 3, there were no differences $(P=0.127$ to 0.688$)$ between experimental groups either in ADFI, ADG or G:F, and no interactions between diet and time were observed, with the exception of a trend for ADFI $(P=0.093)$. These results indicate that the level of inclusion of a supplement derived from fish oil used in our study had no detrimental effect either on feed intake or on animal growth. In agreement with our results, Kowalska and Bielanski (2009) reported no effects of dietary fish oil supplementation ( $3 \%$ as-fed basis) on growth performance of rabbits and feed conversion efficiency. Using other PUFA-rich fats [palm fat ( $99 \%$ SFA) or linseed oil ( $>70 \%$ PUFA)], Trebušak et al. (2015) also observed no differences in growth performance. Nonetheless, others (Bianchi et al., 2009; Casado et al., 2013) have reported lower growing performance when linseed or linseed oil was included in the diet. Both FA composition of the supplements and level of fat inclusion in the diet can be involved in the variable response of rabbits to fat supplementation observed in the different studies. Values of ADFI, ADG, and G:F during the first 3 wk of the study were similar to those reported in the literature for similar production conditions (Fernández et al., 1994; Kouba et al, 2008; Kowalska and Bielanski, 2009), but a lack of increase in feed intake and a reduced growth were observed at wk 4 in both groups, which was 
Table 3. Average daily feed intake, ADG, and G:F of fattening rabbits fed a control diet and an enriched diet with a supplement based on n-3 PUFA (Enriched) from 30 to $60 \mathrm{~d}^{\text {of }}$ age $^{1}$. All values are least squares means

\begin{tabular}{|c|c|c|c|c|c|c|c|c|c|}
\hline \multirow[b]{2}{*}{ Iten } & \multicolumn{4}{|c|}{ Week of growing period } & \multirow[b]{2}{*}{$\operatorname{SEM}_{\mathrm{D}}{ }^{2}$} & \multirow[b]{2}{*}{$\mathrm{SEM}_{\mathrm{T}}{ }^{2}$} & \multicolumn{3}{|c|}{$P$-value } \\
\hline & 1 & 2 & 3 & 4 & & & Diet & Time & Diet $\backslash$ Time \\
\hline \multicolumn{10}{|l|}{$\overline{\mathrm{ADFI}, \mathrm{g} / \mathrm{d}}$} \\
\hline Control & 84.5 & 131 & 146 & 145 & 0.52 & 0.74 & 0.688 & $<0.001$ & 0.093 \\
\hline Enriched & 86.0 & 138 & 143 & 137 & & & & & \\
\hline \multicolumn{10}{|l|}{$\mathrm{ADG}, \mathrm{g} / \mathrm{d}$} \\
\hline Control & 48.6 & 52.2 & 46.4 & 32.7 & 1.12 & 1.58 & 0.144 & $<0.001$ & 0.433 \\
\hline Enriched & 49.0 & 52.0 & 43.6 & 30.9 & & & & & \\
\hline \multicolumn{10}{|l|}{$\mathrm{G}: \mathrm{F}, \mathrm{g} / \mathrm{g}$} \\
\hline Control & 0.575 & 0.401 & 0.318 & 0.226 & 0.0048 & 0.0067 & 0.127 & $<0.001$ & 0.626 \\
\hline Enriched & 0.574 & 0.378 & 0.302 & 0.222 & & & & & \\
\hline
\end{tabular}

${ }^{1}$ Six litters of 8 rabbits each were fed each diet.

${ }^{2} \mathrm{SEM}_{\mathrm{D}}$ and $\mathrm{SEM}_{\mathrm{T}}$ : standard error of the mean for diet and time effects, respectively,

attributed to the high density of rabbits in the cage at the end of the growing period. Muguerza et al. (2008) reported that a density of $0.044 \mathrm{~m}^{2}$ per animal was optimal to reach a slaughter BW of 2.0 to $2.1 \mathrm{~kg}$ in 56 to $60 \mathrm{~d}$ (typical values for rabbit production in Spain), but in our study the density was higher $(0.038 \mathrm{~m} 2$ per animal) and the animals occupied most of the floor space in the cage the last wk of the study. This probably made difficult the access to the feeder and consequently reduced feed intake, which was lower than that reported by others in similar studies (>155 g/d; Corrent et al., 2007; Casado et al., 2013). However, the lack of morbidity and mortality registered in our study indicates that the reduced feed intake did not negatively affect the health of the rabbits in any group. As observed by others (Gutiérrez et al., 2002; Read et al., 2016), G:F was decreasing over time, as feed conversion rate is more favorable in younger animals than in those reaching slaughter BW (Maertens, 2009).

No differences ( $P=0.160$ to 0.842$)$ between diets were observed either in BW at slaughter, hot and chilled carcass weights, carcass yield, drip loss percentage, and full gastrointestinal tract weight (Table 4). Values were in the range of those reported in the literature for similar rabbit production systems (Chamorro et al., 2007; Casado et al, 2011; El Abed et al, 2012). The type of fat in the diet had no effect ( $P=0.144$ to 0.935 ) either in meat color parameters measured 30 min after slaughter or in $\mathrm{pH}$ values at $0,30 \mathrm{~min}$ and $24 \mathrm{~h}$ after slaughter. Nonetheless, the weight of the skin tended to be lower $(P=0.055)$ in the enriched group than in control one. This trend might be due to a higher deposition of subcutaneous fat with a more saturated profile in the control group, which would result in higher fat densification and therefore subcutaneous fat would be more easily removed at skinning. This hypothesis is also supported by the higher amount of perirenal fat ( $P$ $=0.020)$ and the trend $(P=0.063)$ to higher abdominal
Table 4. Body weight, main traits and fat content of carcass, and tissue (bone, muscle and fat) composition of the left hind leg from growing rabbits fed a control diet and an enriched diet with a supplement based on n-3 PUFA (Enriched) and slaughtered at $60 \mathrm{~d}$ of age ${ }^{\mathrm{l}}$. All values are least squares means

\begin{tabular}{|c|c|c|c|c|}
\hline \multirow[b]{2}{*}{ Item } & \multicolumn{2}{|c|}{ Diet } & \multirow[b]{2}{*}{ SEM } & \multirow[b]{2}{*}{$P$-value } \\
\hline & Control & Enriched & & \\
\hline$\overline{B W, g}$ & 1,999 & 1,971 & 13.4 & 0.205 \\
\hline \multicolumn{5}{|l|}{ Carcass traits } \\
\hline Hot carcass weight, $\mathrm{g}$ & 1,197 & 1,177 & 9.2 & 0.221 \\
\hline Hot carcass yield, $\%$ & 59.9 & 59.8 & 0.24 & 0.823 \\
\hline Chilled carcass weight, g & g 940 & 925 & 7.4 & 0.160 \\
\hline \multicolumn{5}{|l|}{ Color } \\
\hline $\mathrm{L}^{*}$ & 54.9 & 54.4 & 0.52 & 0.497 \\
\hline$a^{*}$ & 3.11 & 3.51 & 0.348 & 0.414 \\
\hline $\mathrm{b}^{*}$ & 1.25 & 1.19 & 0.342 & 0.297 \\
\hline \multicolumn{5}{|l|}{$\mathrm{pH}$} \\
\hline Slaughter time & 7.40 & 7.48 & 0.039 & 0.144 \\
\hline $30 \min$ & 7.03 & 7.11 & 0.036 & 0.166 \\
\hline $24 \mathrm{~h}$ & 6.05 & 6.05 & 0.029 & 0.935 \\
\hline Drip loss percentage, $\%$ & 7.30 & 7.42 & 0.165 & 0.431 \\
\hline Skin weight, $\mathrm{g}$ & 387 & 374 & 4.685 & 0.055 \\
\hline $\begin{array}{l}\text { Full gastrointestinal tract } \\
\text { weight, } \mathrm{g}\end{array}$ & 325 & 325 & 5.9 & 0.842 \\
\hline \multicolumn{5}{|l|}{ Fat, $\mathrm{g}$} \\
\hline Abdominal & 26.2 & 24.4 & 0.65 & 0.063 \\
\hline Scapular & 7.11 & 7.19 & 0.272 & 0.851 \\
\hline Perirenal & 14.7 & 12.8 & 0.57 & 0.020 \\
\hline \multicolumn{5}{|l|}{ Left hind leg, g } \\
\hline Total weight & 170 & 169 & 1.467 & 0.403 \\
\hline Bone & 26.7 & 26.2 & 0.27 & 0.253 \\
\hline Muscle & 131 & 129 & 1.5 & 0.299 \\
\hline Fat & 5.22 & 5.20 & 0.183 & 0.946 \\
\hline
\end{tabular}

${ }^{1}$ Twenty-four rabbits per group. 
fat observed in the control group than in the enriched one, although there were no differences $(P=0.851)$ between groups in the amount of scapular fat. A decrease in carcass fat content after PUFA-rich fat supplementation have been previously observed by others in rabbits (Kowalska and Bielanski, 2009; Volek and Marounek, 2011), as fat deposition is affected by the saturation degree of FA (Lin et al., 1993). It has been consistently reported (Piers et al., 2002; Ukropec et al., 2003; Jans et al., 2012) that PUFA are more readily oxidized than SFA, mainly in the liver, but also in the muscle, which can contribute to the reduction on lipogenesis by $\mathbf{n}-3$ PUFA supplementation that has been repeatedly shown in different animal species (Wood et al., 2008). No dif-

Table 5. Total lipids content, fatty acid profile (g/I00 $\mathrm{g}$ total fatty acid methyl esters), and indexes related to human health in LM of growing rabbits fed a control diet and an enriched diet with a supplement based on n-3 PUFA (Enriched) and slaughtered at $60 \mathrm{~d}$ of age ${ }^{l}$. All values are least squares means

\begin{tabular}{|c|c|c|c|c|}
\hline \multirow[b]{2}{*}{ Item } & \multicolumn{2}{|c|}{ Diet } & \multirow[b]{2}{*}{ SEM } & \multirow[b]{2}{*}{$P$-value } \\
\hline & Control & Enriched & & \\
\hline Total lipids, g $100 \mathrm{~g}$ & 1.63 & 1.52 & 0.078 & 0.476 \\
\hline \multicolumn{5}{|l|}{ Fatty acid profile } \\
\hline C12:0 & 0.39 & 0.36 & 0.031 & 0.591 \\
\hline C14:0 & 2.43 & 2.49 & 0.200 & 0.831 \\
\hline C16:0 & 23.4 & 22.1 & 0.729 & 0.209 \\
\hline C18:0 & 6.43 & 6.14 & 0.141 & 0.158 \\
\hline$C 20: 0$ & 0.13 & 0.29 & 0.033 & 0.003 \\
\hline Total SFA & 38.6 & 39.5 & 0.227 & 0.012 \\
\hline C16:ln-7 & 2.64 & 2.64 & 0.198 & 0.993 \\
\hline C'18:ln-9 & 21.6 & 17.5 & 0.647 & $<0.001$ \\
\hline C18:ln-7 & 1.34 & 1.23 & 0.039 & 0.072 \\
\hline$C 20: \ln -9$ & 0.38 & 0.27 & 0.038 & 0.002 \\
\hline Total MUFA & 27.8 & 23.9 & 0.797 & 0.002 \\
\hline$C 18: 2 n-6$ & 19.1 & 15.0 & 0.578 & $<0.001$ \\
\hline C18:3n-3 & 0.93 & 0.95 & 0.062 & 0.768 \\
\hline$C 20: 4 n-6$ & 4.63 & 4.37 & 0.222 & 0.424 \\
\hline C20:5n-3 & 0.80 & 2.59 & 0.095 & $<0.001$ \\
\hline$C 22: 5 n-3$ & 2.52 & 5.28 & 0.520 & $<0.001$ \\
\hline C $22 ; 6 n-3$ & 0.99 & 4.34 & 0.268 & $<0.001$ \\
\hline Total PUFA & 33.6 & 36.6 & 0.860 & 0.021 \\
\hline n- 6 & 23.8 & 19.4 & 0.517 & $<0.001$ \\
\hline n-3 & 5.24 & 13.2 & 0.788 & $<0.001$ \\
\hline n-6in-3 ratio & 5.80 & 1.61 & 0.643 & $<0.001$ \\
\hline Unsaturation inde $x^{2}$ & 1.24 & 1.52 & 0.013 & $<0.001$ \\
\hline Atherogenic index ${ }^{3}$ & 0.79 & 0.51 & 0.043 & $<0.001$ \\
\hline Thrombogenic inde $x^{4}$ & 0.53 & 0.51 & 0.017 & 0.456 \\
\hline \multicolumn{5}{|c|}{ 'Twelve rabbits per group. } \\
\hline \multicolumn{5}{|c|}{$\begin{array}{l}\text {-Calculated as the sum of the unsaturated fatty acids, each multiplied by } \\
\text { the number of double bonds in their chain, and divided by } 100 \text {. }\end{array}$} \\
\hline \multicolumn{5}{|c|}{${ }^{3}$ Atherogenic index $=(C 12: 0+4 \times C 14: 0+C 16: 0):(\Sigma M U F A+\Sigma n-6+\Sigma n-3)$} \\
\hline \multicolumn{5}{|c|}{${ }^{4}$ Thrombogenic index $=(C 14: 0+C 16: 0+C 18: 0):[0.5 \times \Sigma M U F A+0.5$} \\
\hline
\end{tabular}

ferences ( $P=0.253$ to 0.946 ) between groups were detected in total weight and tissue composition (bone, muscle, and fat) of the left hind leg (Table 4). Similar results have been reported by others in rabbits when the diet was supplemented with fish oil (Kowalska and Bielanski, 2009) or other PUFA-rich fats (Peiretti et al., 2007, Volek and Marounek, 2011).

Fatty acid profile and indexes related to human health of LM and perirenal fat are presented in Tables 5 and 6 , respectively. There was no difference $(P=0.476)$ between groups in total fat content of LM. In contrast, dietary supplementation with fish oil resulted in greater PUFA $(P \leq 0.021)$ and lower $(P \leq 0.002)$ MUFA content in both $\mathrm{LM}$ and perirenal fat. The C20:5n-3, C22:5n-3

Table 6. Fatty acid profiles (g/I00 $\mathrm{g}$ total fatty acid methyl esters) and indexes of relevance for human health of perirenal fat of growing rabbits fed a control diet and an enriched diet with a supplement based on n-3 PUFA (Enriched) and slaughtered at $60 \mathrm{~d}$ of age ${ }^{\mathrm{l}}$. All values are least squares means

\begin{tabular}{|c|c|c|c|c|}
\hline \multirow[b]{2}{*}{ Fatty acid } & \multicolumn{2}{|c|}{ Diet } & \multirow[b]{2}{*}{ SEM } & \multirow[b]{2}{*}{$P$-value } \\
\hline & Control & Enriched & & \\
\hline $\mathrm{Cl} 2: 0$ & 1.32 & 1.24 & 0.043 & 0.172 \\
\hline C14:0 & 4.34 & 4.68 & 0.050 & $<0.001$ \\
\hline $\mathrm{C} 16: 0$ & 29.3 & 29.5 & 0.230 & 0.541 \\
\hline C18:0 & 5.74 & 5.47 & 0.104 & 0.079 \\
\hline $\mathrm{C} 20 \div 0$ & 0.10 & 0.10 & 0.003 & 0.633 \\
\hline Total SFA & 42.5 & 42.2 & 0.263 & 0.546 \\
\hline C16:1n-7 & 3.43 & 4.41 & 0.134 & $<0.001$ \\
\hline C18:ln-9 & 28.0 & 23.0 & 0.177 & $<0.001$ \\
\hline C $18: \ln -7$ & 1.54 & 1.60 & 0.031 & 0.174 \\
\hline C20:ln-9 & 0.53 & 0.61 & 0.010 & $<0.001$ \\
\hline Total MUFA & 34.2 & 30.4 & 0.260 & $<0.001$ \\
\hline C $18: 2 n-6$ & 20.9 & 21.8 & 0.234 & 0.008 \\
\hline$C 18: 3 n-3$ & 1.69 & 1.99 & 0.024 & $<0.001$ \\
\hline$C 20: 4 n-6$ & 0.18 & 0.26 & 0.006 & $<0.001$ \\
\hline$C 20: 511-3$ & nd ${ }^{1}$ & 0.10 & 0.019 & $<0.001$ \\
\hline$C 22: 511-3$ & 0.08 & 0.84 & 0.014 & $<0.001$ \\
\hline$C 22 ; 611-3$ & nd ${ }^{1}$ & 0.93 & 0.013 & $<0.001$ \\
\hline Total PUFA & 23.1 & 27.2 & 0.277 & $<0.001$ \\
\hline$n-6$ & 21.3 & 22.4 & 0.240 & 0.004 \\
\hline$n-3$ & 1.77 & 4.76 & 0.048 & $<0.001$ \\
\hline $\mathrm{n}-6 / \mathrm{n}-3$ ratio & 12.04 & 4.71 & 0.064 & $<0.001$ \\
\hline Unsaturation index ${ }^{2}$ & 0.83 & 0.97 & 0.006 & $<0.001$ \\
\hline Atherogenic index ${ }^{3}$ & 0.84 & 0.86 & 0.010 & 0.138 \\
\hline Thrombogenic inde $x^{4}$ & 1.20 & 0.97 & 0.012 & $<0.001$ \\
\hline
\end{tabular}

'Twelve rabbits per group.

'Calculated as the sum of the unsaturated fatty acids, each multiplied by the number of double bonds in their chain, and divided by 100 .

${ }^{3}$ Atherogenic index $=(C 12: 0+4 \times C 14: 0+C 16: 0) /\left(\sum M U F A+\Sigma n-6+\Sigma n-3\right)$.

${ }^{4}$ Thrombogenic index $=(C 14: 0+C 16: 0+C 18: 0):[0.5 \times \Sigma M U F A+0.5$ $\times \Sigma n-6+3 \times \Sigma 0-3+(\Sigma n-6 / \Sigma n-6)]$. 
and C22:6n-3 content of LM was 3.2, 2.I and 4.4 times greater $(P<0.001)$ in the enriched rabbits compared with control ones. Although these FA were not supplied by the control diet (Table 1), the 3 FA were detected in all samples of LM from control animals, thus reflecting the ability of rabbits to synthesize endogenous n-3 FA (Bernardini et al., 1999). The amount of endogenous n-3 FA synthesized seems to depend on dietary n-6/n-3 PUFA ratio, and Bernardini et al. (1999) reported an efficient conversion of $\alpha$-linolenic acid (Cl8:3n-3) into longchain n-3 PUFA in rabbits fed diets with low $\mathbf{n}-6 / n-3$ ratio. An increase in the $\mathrm{C} 20: 5 n-3, C 22: 5 n-3$ and $C 22: 6 n-3$ content in rabbit carcass has also been observed by dietary C18:3n-3 supplementation (Bernardini et al., 1999; Kouba, 2006), although the level of C18:3n-3 that can be converted into $\mathrm{C} 20 \cdot 5 n-3$ and $\mathrm{C} 22 \cdot 6 \mathrm{n}-3$ appears to be variable in different body tissues, with the heart and the liver having greater capacity than the muscle (Ander et al., 2010). In our study there were no differences ( $P=$ 0.768 ) between diets in $\mathrm{Cl} 8: 3 \mathrm{n}-3$ concentrations in LM. Total SFA content in perirenal fat was not affected by the type of fat in the diet, but SFA content in LM was greater $(P=0.012)$ in the enriched group than in control one; this was due to the greater $(P=0.003) \mathrm{C} 20: 0$ concentrations observed in enriched rabbits, as there were no differences between diets $(P \geq 0.158)$ in the rest of analyzed SFA. In agreement with our results, previous studies have shown the influence of dietary FA profile on FA deposition in rabbit carcass (Xiccato, 1999; Benatmane et al., 2011; Tres et al., 2014). In addition, good relationships between dietary FA and their content in LM and perirenal fat have been reported by Peiretti (2012) in a review of studies involving 27 diets varying in FA profile. However, individual FA differed in their incorporation in muscle and fat, and regression equations of individual FA in LM and perirenal fat on the same FA in the diet were different for the 2 tissues (Peiretti, 2012). A different response to dietary FA in LM and perirenal fat was also observed in our study, as long-chain n-3 PUFA concentrations and $n-6 / n-3$ ratio in PUFA rabbits were greater and lower, respectively, in LM than in perirenal fat. In addition, no C20:5n-3 and C22:6n-3 were detected in the perirenal fat of control rabbits, but both were detected in the LM samples of the same animals. The FA profile observed in our study is consistent with previous work (Bernardini et al., 1999; Kouba et al, 2008; Peiretti, 2012), showing greater SFA and MUFA deposition in fat compared with muscle, but greater PUFA deposition in muscle than in fat. It has to be noticed that the major lipid class in adipose tissue is triacylglycerol or neutral lipid, whereas in muscle a significant proportion is phospholipid, which has a much higher PUFA content in order to perform its function as a constituent of celular membranes (Wood et al., 2008). The FA profile in neutral lipids and phospholipids differ considerably, which can help to explain the the different individual FA incorporation observed in LM and perirenal fat.

The atherogenic and thrombogenic indexes can be considered a measure of the atherogenic and thrombogenic potential for human consumption, respectively, of the fat deposited in the carcass (Ulbricht and Southgate, 1991). The LM and perirenal fat from enriched rabbits showed lower $(P<0.00 \mathrm{I})$ atherogenic and thrombogenic indexes, respectively, than those from unsupplemented rabbits. Values of both indexes showed more individual variability in LM than in perirenal fat, but they indicate that carcass from enriched rabbits had a higher nutritional quality than that from control rabbits. Moreover, the $n-6 / n-3$ ratio in the muscle of PUFA enriched rabbits was in the range recommended for healthy eating ( $<$ 4.0; Simopoulos, 2002; Wood et al., 2004), whereas meat from control rabbits exceeded this value.

\section{Cecal Fermentation and Ileal Morphology}

There were no differences ( $P=0.126$ to 0.924$)$ between groups either in full cecum or cecal content weight at any sampling time (data not shown; averaged values across sampling times: 56.1 and $34.7 \mathrm{~g}$ for control diet, and 58.0 and $37.0 \mathrm{~g}$ for enriched diet, respectively). As shown in Table 7, control rabbits showed greater DM content $(P=0.005)$ and lower $(P<0.001)$ total VFA concentrations in the cecum than those fed the enriched diet, but diet did not affect $(P>0.05)$ cecal $\mathrm{pH}$ or $\mathrm{NH}_{3}-\mathrm{N}$ concentrations. The reason for the greater total VFA concentration in the cecum of enriched rabbits is unclear, but it might reflect greater fementation activity, although VFA concentrations do not necessarily reflect changes in VFA production if there are concomitant changes in VFA absorption and/or digesta passage rate. Some studies have shown that n-3 PUFA supplementation can modify the intestinal microbiota in poultry (Knarreborg et al., 2002) and pigs (Andersen et al., 2011), and it has been suggested that n-3 PUFA can protect against dysbiosis (Ghosh et al., 2013). Some studies in rabbits have reported that dietary supplementation with caprylic and capric acids decreased bacterial shedding in rabbits infected with enteropathogenic $E$. coli (Skřvanová and Marounek, 2006; Skřivanová a et al., 2009) and other FA had antimicrobial activity on selected microorganisms (Marounek et al., 2002), but to our best knowledge there is no information on the effects of n-3 PUFA on rabbits gut microbiota. There were no differences between groups in VFA profile, with the exception of the proportion of minor VFA (calculated as the sum of isobutyrate, isovalerate, and valerate), which was greater $(P=0.013)$ in control than in supplemented rabbits. The lack of differences between diets in the proportions of the main VFA and $\mathrm{NH}_{3}-\mathrm{N}$ 
Table 7. Dry matter content, $\mathrm{pH}$ values, and $\mathrm{NH}_{3}-\mathrm{N}$ and VFA concentrations in the cecum and ileal morphology of growing rabbits fed control diet and an enriched diet with a supplement based on n-3 PUFA (Enriched) and slaughtered at 30 (weaning), 45 , and $60 \mathrm{~d}$ of age ${ }^{1}$. All values are least squares means

\begin{tabular}{|c|c|c|c|c|c|c|c|c|}
\hline \multirow[b]{2}{*}{ Item } & \multicolumn{3}{|c|}{ Age, d } & \multirow[b]{2}{*}{$\mathrm{SEM}_{\mathrm{D}}^{2}$} & \multirow[b]{2}{*}{$\mathrm{SEM}_{\mathrm{T}}{ }^{2}$} & \multicolumn{3}{|c|}{$P$-value } \\
\hline & 30 & 45 & 60 & & & Diet & Time & Diet \Time \\
\hline \multicolumn{9}{|l|}{ Caceum } \\
\hline \multicolumn{9}{|l|}{ DM, $\%$} \\
\hline Control & 22.8 & 23.2 & 22.4 & 0.24 & 0.29 & 0.005 & 0.512 & 0.627 \\
\hline Enriched & 21.5 & 22.0 & 21.9 & & & & & \\
\hline \multicolumn{9}{|l|}{$\mathrm{pH}$} \\
\hline Control & 5.78 & 5.92 & 5.72 & 0.029 & 0.036 & 0.749 & $<0.001$ & 0.036 \\
\hline Enriched & 5.93 & 5.94 & 5.59 & & & & & \\
\hline \multicolumn{9}{|l|}{$\mathrm{NH}_{3}-\mathrm{N}, \mathrm{mg} / \mathrm{L}$} \\
\hline Control & 101 & 123 & 92 & 7.9 & 9.6 & 0.926 & 0.121 & 0.631 \\
\hline Enriched & 89 & 122 & 107 & & & & & \\
\hline \multicolumn{9}{|c|}{ Total VFA, mmolig } \\
\hline Control & 43.8 & 64.2 & 72.8 & 2.02 & 2.47 & $<0.001$ & $<0.001$ & 0.109 \\
\hline Enriched & 62.5 & 86.8 & 80.4 & & & & & \\
\hline \multicolumn{9}{|c|}{ Molar proportions (mol/100 mol) } \\
\hline Acetate & 85.4 & 78.3 & 73.9 & 0.47 & 0.58 & 0.332 & $<0.001$ & 0.819 \\
\hline Control & 86.1 & 78.4 & 75.1 & & & & & \\
\hline \multicolumn{9}{|l|}{ Enriched } \\
\hline \multicolumn{9}{|l|}{ Propionate } \\
\hline Control & 3.59 & 4.44 & 5.01 & 0.182 & 0.223 & 0.688 & 0.039 & 0.115 \\
\hline Enriched & 4.22 & 4.79 & 4.34 & & & & & \\
\hline \multicolumn{9}{|l|}{ Butyrate } \\
\hline Control & 10.1 & 15.4 & 19.1 & 0.38 & 0.47 & 0.431 & $<0.001$ & 0.744 \\
\hline Enriched & 9.1 & 15.2 & 19.0 & & & & & \\
\hline \multicolumn{9}{|l|}{ Minor VFA ${ }^{3}$} \\
\hline Control & 0.95 & 1.88 & 2.00 & 0.090 & 0.110 & 0.013 & $<0.001$ & 0.912 \\
\hline Enriched & 0.65 & 1.58 & 1.58 & & & & & \\
\hline \multicolumn{9}{|l|}{ Ileal morphology } \\
\hline \multicolumn{9}{|c|}{ Crypt depth, $\mu \mathrm{m}$} \\
\hline Control & - & 131 & 138 & 2.1 & 2.6 & 0.319 & 0.012 & 0.979 \\
\hline Enriched & - & 131 & 146 & & & & & \\
\hline \multicolumn{9}{|c|}{ Villi length, $\mu \mathrm{m}$} \\
\hline Control & - & 501 & 471 & 10.5 & 12.8 & 0.255 & 0.619 & 0.376 \\
\hline Enriched & - & 450 & 480 & & & & & \\
\hline
\end{tabular}

${ }^{1}$ Six litters ( 8 rabbits each) were fed each diet, and 2 rabbits per cage were sampled at each time $(n=6)$.

${ }^{2} \mathrm{SEM}_{\mathrm{D}}$ and $\mathrm{SEM}_{\mathrm{T}}$ : standard error of the mean for diet and time effects, respectively.

${ }^{3}$ Calculated as the sum of isobutyrate, isovalerate, and valerate.

concentrations observed in our study might indicate that the activity of the microbiota rather than the microbiota itself was affected by PUFA supplementation. Total VFA concentrations were $1.43,1.35$, and 1.10 times greater in enriched rabbits than in control ones at 30,45 , and $60 \mathrm{~d}$ of age, respectively, indicating that differences became less marked with age. Rabbit does received the same experimental diet than their litters during gestation and lactation, and therefore differences in cecal VFA concentrations at weaning $(30 \mathrm{~d})$ might be partly due to differences in milk FA profile, as it has been shown that supplementing the diet of does with fish oil resulted in increased $\mathbf{n}-3$ PUFA content in milk (Febrel et al., 2015). In agreement with previous observations (Gidenne and Bellier, 2000), total VFA concentrations increased $(P<0.001)$ and molar proportions of acetate and butyrate decreased $(P<$ $0.001)$ and increased $(P<0.00 \mathrm{I})$, respectively, from 30 to $60 \mathrm{~d}$ of age. Cecal $\mathrm{pH}$ decreased $(P<0.001$ ) with age, which is in accordance with the increased VFA concentrations observed over time.

Diet did not affect ileal crypt depth $(\mathrm{P}=0.319)$ or villi length ( $P=0.255$ ), indicating no effect of fish oil supplementation on the development of the ileal mucosa. Whereas ileal crypt depth increased $(P=0.012)$ from 45 to $60 \mathrm{~d}$ of age, no changes $(P=0.619)$ in villi length were detected. There were no diet $\times$ time interac- 
tions $(P=0.115$ to 0.979$)$ in any cecal and ileal parameter analyzed, with the exception of cecal $\mathrm{pH}(P=0.036)$.

Finally, it is worth it to mention that right hind legs were cooked (fried in olive oil without any condiment) and assessed by an untrained panel of 12 people, who did not find any abnormal odor or flavor in the enriched group (data not shown)

In conclusion, replacing lard by a supplement derived from fish oil in the diet of rabbits changed the FA profile of meat and fat depots, resulting in a more favorable profile for human nutrition, reduced the perirenal and abdominal fat content and had no adverse effects on growth performance, carcass characteristics and ileal morphology. The reason for the increased total VFA concentrations in the cecum of rabbits fed a supplement derived from fish oil should be further investigated.

\section{LITERATURE CITED}

Ander, B. P., A. L. Edel, R. McCullongh, D. Rodrignez-Leyva, P. Rampersad, I. S. C. Gilchrist, A. Lukas, and G. N. Pierce. 2010. Distribution of omega-3 fatty acids in tissues of rabbits fed a flaxseed-supplemented diet. Metabolism 59:620-627. doi: 10.1016/j.metabol.2009.09.005

Andersen, A. D., L. Molbak, T. Thymann, K. F. Michaelsen, and L. Lauritzen. 2011. Dietary long-chain n-3 PUFA, gut microbiota and fatmass in early postnatal piglet development - exploring a potential interplay. Prostaglandins Leukot. Essent. Fatty Acids 85:345-351, doi:10.1016/j.plefa.2011.08.004

AOAC. 2000. Official methods of analy sis of the Association of Official Agricultural Chemists. 18th ed. AOAC Intemational, Arlington, VA.

Benatmane, F., M. Kouba, A. Youyou, and J. Mourot. 2011. Effect of a linseed diet on lipogenesis, fatty acid composition and stearoyl-CoA-desaturase in rabbits. Animal 5:1993-2000. doi: $10.1017 / \mathrm{S} 1751731111001145$

Bemardini, M., A. Dal Bosco, and C. Castellini. 1999. Effect of dietary n-3/n-6 ratio on fatty acid composition of liver, meat and perirenal fat in rabbit. Anim. Sci. 68:647-654. doi:10.1017/ S1357729800050682

Bianchi, M., M. Petracci, and C. Cavani. 2009. The influence of linseed on rabbit meat quality. World Rabbit Sci. 17:97-107. doi: 10.4995 wrs. 2009.663

Blasco, A., J. Ouhayoun, and G. Masoero. 1993. Harmonization of Criteria and Terminology in Rabbit Meat Research. World Rabbit Sci. 1:3-10. doi: 10.4995/wrs. 1996.278

Boletín Oficial del Estado (BOE). 2013. (In Spanish) Real Decreto $53 / 2013$, de 1 de febrero, por el que se establecen las normas básicas aplicables para la protección de los animales utilizados en experimentación y otros fines científicos, incluyendo la docencia. Bol. Of. Estado 34:11370-11421.

Casado, C., V. J. Moya, J. J. Pascual, E. Blas, and C. Cervera. 2011. Effect of oxidation state of dietary sunflower oil and dietary zinc and $\alpha$-tocopheryl acetate supplementation on performance of fattening rabbits. World Rabbit Sci. 19:191-202. doi: $10.4995 /$ ws 2011.940

Casado, C., V. I. Moya, J. J. Pascual, E. Blas, and C. Cervera. 2013. Dietary fatty acid profile: effects on caecal fermentation and performance of youngs and fattening rabbits. World Rabbit Sci. 21:235-242. doi: 10.4995/wrs.2013.1437
Castellini, C., A. dal Bosco, R. Cardinalu, C. Mugnai, and E. Sciascia. 2004. Effects of dietary n-3 fatty acids on the composition of doe's milk and tissues of suckling rabbits. In: Becerril C. M. and A. Pro, editors, Proc. of the 8th World Rabbit Congress. p. 771-777.

Chamorro, S., M. S. Gomez-Conde, A. M. Perez de Rozas, R. Carabario, and C. De Blas. 2007. Effect on digestion and performance of dietary protein content and of increased substitution of luceme hay with soya-bean protein concentrate in starter diets for young rabbits. Animal 1:651-659, doi:10.1017/\$1751731107708273

Commission Internationale de L'Eclairage (CIE). 2004. Technical Report. Colorimetry, 3rd ed., Vienna, Ausria.

Corrent, E., C. Lannay, G. Troislouches, F. Viard, C. Davoust, and C. Leroux. 2007. Impact d'une substitution d'anidon par des lipides sur l'indice de consommation du lapin en fin d'engraissement. In: Proc. 12èmes J. Rech. Cunicole, Le Mans, France. p. 97-100.

De Blas, C., and G. G. Mateos. 2010. Feed formulation. In: C. De Blas and J. Wiseman, editors, Nutrition of the rabbit. 2nd ed. CABI Publishing CAB International, Wallingford, UK. p. 222-232. doi: $10.1079 / 9781845936693,0222$

El Abed, N., D. Menoyo, J. Garcia, R. Carabaño, A. Pérez de Rozas, I. Badiola, M. A. Eras, M. Tazzoli, A. Trocino, D Majolini, and G. Xiccato. 2012. Dietary supplementation with mannanoligosaccharides and $\beta$-glucans in growing rabbits. 2. Gut barrier and intestinal microbiota after weaning. En: 10th World Rabbit Congress. p: $673-677$.

Febrel N., M. Rodriguez, B. Velasco, I. López-Tello, R. M. GarciaGarcia, M. Arias-Alvarez, P. L. Lorenzo, and P. G. Rebollar. 2015. Effect of litter size and polyunsaturated fatty acid n-3 supplementation in lactating rabbit does. World Rabbit Sci., 23:136 (Abstr.). doi: 10.4995/wrs.2015.3901.

Femández, C., A. Cobos, and M. J. Fraga. 1994. The effect of tat inclusion on diet digestibility in growing rabbits. J. Anim. Sci. $72: 1508-1515$.

Fortun-Lamothe, L., and S. Boullier. 2007. A review on the interactions between gut microflora and digestive mucosal immunity. Possible ways to improve the health of rabbits. Livest. Sci. 107:1-18. doi:10.1016/j.livsci.2006.09.005

Garcia-Martinez, R., M. J. Ranilla, M. L. Tejido, and M. D. Carro. 2005. Effects of disodium fumarate on in vitro rumen microbial growth, methane production and fermentation of diets differing in their forage:concentrate ratio. Br. J. Nutr. 94:7177. doi: 10.1079/BJN20051455

Ghosh, S., E. Molcan, D. DeCoffe, and D. L. Gibson. 2013. Diets rich in $n-6$ PUFA induce intestinal microbial dysbiosis in aged mice. Br. J. Nutr. 110515-523. doi:10.1017/S0007114512005326

Gidenne, T, and R. Bellier. 2000 . Use of digestible fiber in replacement to available carbohydrates. effect on digestion, rate of passage and caecal fermentation pattern during the growth of the rabbit. Livest. Prod. Sci. 63:141-152, doi:10.1016/S0301-6226999)00123-2

Gil, A., and F. Gil. 2015. Fish, a Mediterranean source of n-3 PUFA: benefits do not justify limiting consumption. Br. J. Nutr. 113:S58-S67. doi: 10.1017/S0007114514003742

Gutiérrez, I., A. Espinosa, J. García, R. Carabaño, and J. C. De Blas. 2002. Effect of levels of starch, fiber, and lactose on digestion and growth performance of early-weaned rabbits. $\mathrm{J}$. Anim. Sci. 80: 1029-1037. doi: 10.2527/2002.8041029x

Hampson, D. J. 1986. Alterations in piglet small intestinal structure at weaning. Res. Vet. Sci. 40:32-40.

Jans, A., E. Konings, G. H. Goossens, F. G. Bouwman, C. C. Moors, M. V. Boekschoten, L. A. Afman, M. Müller, E. C. Mariman, and E. E. Blaak. 2012. PUFAs acutely affect triacylglycerol-derived skeletal muscle fatty acid uptake and increase postprandial insulin sensitivity. Am. J. Clin. Nutr. 95:825-836. doi:10.3945/ajcn.111.028787 
Knarreborg, A., M. A. Simon, R. M. Engberg, B. B. Jensen, and G. W Tannock. 2002. Effects of dietary fat source and subtherapeutic levels of antibiotic on the bacterial community in the ileum of broiler chickens at various ages. Appl. Environ. Microbiol. 68:5918-5924. doi:10.1128/AEM.68.12.5918-5924.2002

Kouba, M. 2006. Effect of dietary omega-3 fatty acids on meat quality of pigs and poultry. In: M. C. Teale, editor, Omega-3 Fatty Acid Research. Nova Science Publishers, Hauppauge, NY. p. 225-239.

Kouba, M., F. Benatmane, J. E. Blochet, and J. Mourot. 2008. Effect of a linseed diet on lipid oxidation, fatty acid composition of muscle, perirenal fat, and raw and cooked rabbit meat. Meat Sci. 80:829-834. doi: 10.1016/j.meatsci.2008.03.029

Kowalska, D., and P. Bielanski. 2009. Meat quality of rabbit fed a diet supplemented with fish oil and antioxidant. Anim. Sci. Pap. Rep. 27:139-148.

Lin, D. S., W. E. Connor, and C. W. Spenler. 1993. Are dietary saturated, monounsaturated, and polyunsaturated fatty acids deposited to the same extent in adipose tissue of rabbits? Am. J. Clin. Nutr. 58:174-179.

Maertens, L. 2009. Possibilities to reduce the feed conversion in rabbit production In: Proc. Gionnate di Coniglicoltura. ASIC, Forly, Italy. p. 1-10.

Maertens, L., J. M.Aerts, and D. L. De Brabander. 2005. Effect of a diet rich in $\mathrm{n}-3$ fatty acids on the performances and milk composition of does and the viability of their progeny. In: Proc. 11 ime I. Rech. Cunicole, Paris, France. p. 205-208.

Marounek, M., V. Skrivanova, and O. Savka. 2002. Effect of caprylic, capric and oleic acid on growth of rumen and rabbit caecal bacteria. J.Anim. Feed Sci. 11:507-516. doi: 10.22358/jats/67904/2002

Muguerza, M. A., I. García, and P. Eguinoa. 2008. (In Spanish) Efecto de la densidad de conejos sobre los resultados técnicoeconómicos. Navarra Agraria 171:33-38.

Peiretti, P. G. 2012. Effects of Dietary Fatty Acids on Lipid Traits in the Muscle and Perirenal Fat of Growing Rabbits Fed Mixed Diets. Animals (Basel) 2:55-67, doi: 10.3390/ani2010055

Peiretti, P. G., P. P. Mussa, L. Prola, and G. Meineri. 2007. Use of different levels of false flax (Camelina sativa $L$.) seed in diets for fattening rabbits. Livest. Sci. 107:192-198. doi:10.1016/j. livsci.2006.09.015

Piers, L. S., K. Z. Walker, R. M. Stoney, M. J. Soares, and K. O'Dea. 2002. The influence of the type of dietary fat on postprandial fat oxidation rates: monounsaturated (olive oil) vs saturated fat (cream). Int. J. Obes. Relat. Metab. Disord. 26:814-821. doi:10.1038/sj.ijo.0801993

Read, T., S. Combes, T. Gidenne, N. Destombes, K. Bébin, E. Balmisse, and $\mathrm{L}$. Fortun-Lamothe. 2016. Influence of feding strategy and diet for reproductive rabbit does on intake, performances, and health of young and females before and after weaning. I. Anim. Sci. 94:4848-4859. doi: $10.2527 /$ jas. 2016-0678

Rebollar, P. G., R. M. García-García, M. Arias-Álvarez, P. Millán, A. I. Rey, M Rodríguez, N. Formoso-Raffèty, S. de la Riva, M. Masdeu, P. L. Loremzo, and P. García-Rebollar. 2014. Reproductive longterm effects, endocrine response and fatty acid profile of rabbit does fed diets supplemented with n-3 fatty acids. Anim. Reprod. Sci. 146:202-209. doi:10.1016/j.anireprosci.2014,02.021

Rodriguez, M., R. M. Garcia-Garcia, M. Arias-Álvarez, N. Formoso-Rafferty, P. Millán, J. López-Tello, P. L. Lorenzo, A. González-Bulnes, and P. G. Rebollar. 2017. A diet supplemented with $1-3$ polyunsaturated fatty acids influences the metabolic and endocrine response of rabbit does and their offspring. J. Anim. Sci. doi: 10.2527/jas.2017.1429
Segura, J., and C. J. López-Bote. 2014. A laboratory efficient method for intramuscular fat analysis. Food Chem. 145:821825. doi: $10.1016 /$ j.foodchem.2013.08.131

Simopoulos, A. P. 2002. Omega-3 fatty acids in inflammation and autoimmune diseases. J. Am. Coll. Nutr. 21:495-505. doi: 10 1080/07315724.2002.10719248

Skřivanová, E., Z. Molatová, V. Skřivanová, and M. Marounek. 2009 . Inhibitory activity of rabbit milk and medium-chain fatty acids against enteropathogenic Escherichia coli O128. Vet. Microbiol. 135:358-362, doi:10.1016/j.vetmic 2008.09.083

Skfivanová, V, and M. Marounek. 2006. A note on the effect of triacylglycerols of caprylic and capric fatty acid on performance, mortality, and digestibility of nutrients in young rabbits. Anim. Feed Sci. Teclunol. 127:161-168. doi: 10.1016/j.anifeedsci.2005.07.001

Sukhija, P. S., and D. L. Palmquist. 1988. Rapid method for determination of total fatty acid content and composition of feedstuffs and feces. J. Agric. Food Chem. 36:1202-1206. doi: $10.1021 / \mathrm{j}$ fooos4a019

Trebušak, T., A. Levart, J. Salobir, and T. Pirman 2015. A higher proportion of PUFA in the diet increases the PUFA content in rabbit meat, but reduces the oxidative stability of meat. Poljoprivreda. 21:73-77. doi: $10.18047 /$ poljo.21.1.sup. 16

Tres, A., N. Magrinyà, R. Bou, F. Guardiola, C. D. Nuchi, and R. Codony. 2014. Impact of the oxidative quality of fish oils in feeds on the composition and oxidative stability of cluicken and rabbit meat. Anim. Feed Sci. Technol. 196:76-87. doi:10.1016/j.anifeedsci.2014,06,013

Ukropec, J., J. E. Reseland, D. Gasperikova, E. Demcakova, L. Madsen, R. K. Berge, A. C. Rustan, I. Klimes, C. A. Drevon, and E. Sebökova. 2003. The hypotriglyceridemic effect of dietary n-3 FA is associated with increased $\beta$-Oxidation and reduced leptin expression Lipids 38: 1023-1029. doi: 10.1007/s11745-006-1156-z

Ulbricht, T. L, and D. A. T. Southgate. 1991. Coronary heart disease: seven dietary factors. Lancet 338:985-992. doi: $10.1016 / 0140-6736(91) 91846-\mathrm{M}$

Van Soest, P. J., I. B. Robertson, and B. A. Lewis. 1991. Methods for dietary fiber, neutral detergent fiber, and nonstarch polysaccharides in relation to animal nutrition. I. Dairy Sci. 74:3583-3597. doi: $10.3168 / j d s . S 0022-0302$ (91)78551-2

Volek, Z., and M. Marounek. 2011. Effect of feeding growing-fattening rabbits a diet supplemented with whole white lupin (Lupinus albus cv. Amiga) seeds on fatty acid composition and indexes related to human health in hind leg meat and perirenal fat. Meat Sci. 87:40-45. doi: 10.1016/j.meatsci.2010.08.015

Weatherburn, M. W. 1967. Phenol-hypochlorite reaction for determination of ammonia. Anal. Chem. 39:971-974. doi:10.1021/ ac $60252 a 045$

Wood, J. D., R. I. Richardson, G. R. Nute, V. A. Fisher, M. M. Campo, E. Kasapidou, P. Sheard, and M. Enser. 2004. Effects of fatty acids on meat quality: a review. Meat Sci. 66:21-32. doi:10.1016/ S0309-1740(03)00022-6

Wood, J. D., M. Enser, A. V. Fisher, G. R. Nute, P. R. Sheard, R. I. Richardson, S. I. Hughes, and F. M. Whittington. 2008. Review. Fat deposition, fatty acid composition and meat quality: A review. Meat Sci. 78:343-358. doi:10.1016/j.meatsci.2007.07.019

Xiccato, G. 1999. Feeding and meat quality in rabbits: A review. Work Rabbit Sci. 7:75-86. doi:10.4995/wrs.1999.383 